УДК 336.22-047.74:005.941

DOI: $10.15673 /$ fie.v13i2.2038

\author{
Євтушевська 0.0. \\ кандидат економічних наук, доцент \\ кафедра обліку та аудиту \\ Одеська національна академія харчових технологій \\ вул. Канатна, 112, м. Одеса, Україна, 65039 \\ E-mail: olga163alex@gmail.com \\ ORCID ID: 0000-0003-4869-5123
}

\title{
ПОДАТКОВЕ ПЛАНУВАННЯ У СИСТЕМІ КОРПОРАТИВНОГО ПОДАТКОВОГО МЕНЕДЖМЕНТУ
}

Значення податкового планування на мікроекономічному рівні підприємства важко переоцінити - при правильній реалізації ефективної схеми від такого планування часто залежить не лише швидкість досягення точки беззбитковості і рентабельність інвестицій, а й швидкість розвитку самого підприємства, розширення асортименту, освоєння нових напрямів тощо. Заходи, що разом фрормують систему податкового планування, можуть істотно вплинути на розвиток підприємства 3 першого місяця його діяльності. Залучення до податкового планування профільних спеціалістів, регулярні консультації з фріскальними органами, вивчення чинного законодавства та використання високоефективної системи обліку допомагають зробити бізнес високорентабельним, легальним та потужним. У статті викладено та розглянуто особливості податкового менеджменту на мікрорівні, предмет та фрункції податкового менеджменту, розкрито поняття податкового планування, надано характеристику його основних етапів, необхідність та ефективність податкового планування. Наведено перелік заходів та інструментів податкового планування.

Ключові слова: предмет податкового менеджменту, функції податкового менеджменту, необхідність податкового планування, ефективність податкового планування, заходи податкового планування. інструменти податкового планування.

This work is licensed under a Creative Commons Attribution 4.0 International License http://creativecommons.org/licenses/by/4.0/

Постановка проблеми та її зв'язок з важливими науковими та практичними завданнями. Питання податкового планування актуальні для кожної компанії, незалежно від напрямку ії діяльності. Ця необхідна для ділових людей процедура потребує розгляду в період організації підприємства або при розробці бізнес-проекту. Якщо відкласти питання податкового планування на більш пізній термін, то в подальшому буде дуже складно змінити ситуацію на краще. Планування податків впливає на ефективність роботи організації, тобто дозволяє правильно сформувати податковий облік, управляти витратами і прибутком, впливати на фінансову незалежність. При цьому важливо розуміти, що роботу 3 планування, аналізу та оцінки рівня податків на підприємстві потрібно здійснювати не час від часу, а систематично.

Аналіз останніх публікацій по проблемі. Проблемам податкового менеджменту останнім часом приділяється чимало уваги вітчизняними та зарубіжними науковцями. Займалися і зробили вагомий внесок в їх вирішення такі вітчизняні та зарубіжні вчені і фахівці: М. Бейгельзімер, І. Бланк, А. Горбунов, О. Кірш, А. Крисоватий, А. Кізима, А. Слисеєв, М. Підлужний, К. Ковальчук, Т. Рева. В умовах адаптації податкового законодавства України до законодавства СС податковий менеджмент повинен бути безперервним управлінським процесом, спрямованим на побудову оптимального податкового тиску у поєднанні з реалізацією загальних завдань суб'єкта господарювання. Тому дослідження питання податкового менеджменту на мікрорівні в умовах інтеграції України до ЄС є досить актуальним.

Формування цілей дослідження. Сформовано наступні цілі дослідження: розкрити особливості податкового менеджменту на мікрорівні, предмет та функції податкового менеджменту, необхідність та ефективність податкового планування, різні підходи для визначення його структурних елементів; розглянути перелік заходів та інструментів податкового планування.

Виклад основних результатів та їх обгрунтування. Податковий менеджмент - $є$ одним 3 підвидів фінансового менеджменту, виконуючи відповідну функцію в системі управління.

На макрорівні податковий менеджмент здійснюється в рамках всієї країни державними органами. Це розробка податкової політики в цілому, організація і функціонування всієї податкової системи, вироблення основних пріоритетів на довгострокові і короткострокові періоди, податкове адміністрування і податковий контроль.

На мікрорівні податковий менеджмент спря- 
мований на внутрі фірмове регулювання і включає в себе вибір організаційно-правової форми діяльності з точки зору впливу на податкові платежі, укладення цивільно-правових договорів, оптимальних для організації з позиції податкового права, податкова оптимізація та планування, взаємовідношення і взаємодія 3 податковими органами в процесі щоденної життєдіяльності, а також в спірних і конфліктних ситуаціях, прогнозування позиції податкових органів, а також розвитку всієї податкової політики в країні.

Згідно з тенденціями щодо розвитку корпоративного податкового менеджменту в Україні, складовими системи податкового менеджменту підприємства повинні стати наступні елементи [5,c.117]:

1.Стратегія оптимізації податкових зобов'язань $з$ чітким планом іiї реалізації;

2.Оптимізація договірних відносин 3 контрагентами через вибір типу договору, партнера по бізнесу і умов операції; організація системи бухгалтерського і податкового обліку, що дозволяють оперативно отримувати об'єктивну інформацію для податкового менеджменту;

3.Планування раціонального розміщення активів не тільки з погляду прибутковості інвестицій, але і розмірів податків, що сплачуються при отриманні доходів;

4.Формування облікової політики 3 метою оподаткування, спрямованої на максимальне використання можливостей для зниження податкового тягаря, передбачених податковим законодавством України, які розробляються з урахуванням зовнішніх і внутрішніх чинників;

5.Застосування обгрунтованих i ефективних методик розподілу непрямих витрат, що дозволяють зменшити податкові платежі;

6.Визначення і моніторинг пільг, що діють в поточному і подальшому податкових періодах, якими має право користуватися підприємство;

7.Розробка системи контролю за наднормативними витратами, що не враховуються 3 метою оподаткування.

Таким чином, податковий менеджмент можна визначити як цілеспрямовану, організуючу діяльність суб'єктів, з одного боку - держави, і платників податків 3 іншого, 3 метою найбільш оптимального управління фінансовими активами, які є в наявності.

Податковий менеджмент включає також вироблення пріоритетів на формування і реалізацію податкової політики на макро- і мікрорівнях.

метою податкового планування не мінімізацію, а оптимізацію податкових платежів. При цьому вони вважають, що податкове планування має здійснюватись системно, 3 урахуванням впливу заходів стосовно оптимізації платежів на фінансовий стан підприємства.

При визначенні поняття податкового планування, А. Поршнєв стверджує, що це процес попереднього розгляду й оцінки рішень в галузі фінансовогосподарської діяльності організації з урахуванням величини можливих податкових платежів та забезпе-
Податковий менеджмент являє собою систему, що будується на основі спеціальних принципів, методів, завдань, за допомогою яких здійснюється управління.

Як наукова дисципліна податковий менеджмент вимагає розкриття своїх концептуальних основ, як область практичної діяльності він грунтується на конкретних прийомах і способах прийняття рішень 3 управління оподаткуванням.

Наукова дисципліна, що розглядається, характеризується своїм предметом і методом. При їх трактуванні повинна бути прийнята до уваги двоїста природа податку, тобто податок послідовно розкривається як правова та економіко-вартісна категорія.

Предметом податкового менеджменту є:

- відносини $з$ приводу встановлення, введення та справляння податків;

- податкові ресурси;

- фінансові потоки.

Метод податкового менеджменту охоплює:

- способи впливу права на суспільні відносини $з$ питань оподаткування;

- сукупність прийомів, елементів податкового механізму.

Податковий менеджмент як система управління оподаткуванням підприємства включає в себе чотири основні функції:

1) організація процесу управління податковими потоками на підприємстві;

2) податкове планування;

3) податкове регулювання;

4) податковий контроль.

На думку О.Вилкова і М.Романовського, корпоративне податкове планування на рівні суб'єкта господарської діяльності $є$ невід'ємною частиною управління фінансово-господарською діяльністю в рамках єдиної стратегії його економічного розвитку, що представляє собою процес системного використання оптимальних законних податкових способів i методів для встановлення бажаного майбутнього фінансового стану об'єкта в умовах обмеженості ресурсів і можливості їхнього альтернативного використання [2].

До податкового планування Д.Винокуров відносить довгострокову податкову оптимізацію, що полягає у застосуванні відповідних способів і прийомів, які дозволяють зменшити податкові платежі в процесі всієї діяльності [3].

Більшість авторів вважають чення вибору з них найкращих рішень із позиції загальних цільових установок організації [6].

На нашу думку, податкове планування необхідно розглядати через призму протистояння платника податків, з одного боку, і фіскальних органів, 3 іншого. У той же час воно не тільки зменшує податкові відрахування, а й $є$ регулятором процесу управління підприємством, так як мінімізація і оптимізація податків не завжди відповідають стратегічним потребам господарюючого суб'єкта.

Йому іноді вигідно не занижувати свою базу 
оподаткування в силу тих чи інших причин (наприклад, якщо витрати по мінімізації податкового навантаження перевищують доходи, крім того, керівництво підприємства може відмовитися від податкової мінімізації в силу соціальних і політичних причин). Але така відмова не означає відсутність податкового планування. Таким чином, податкове планування - інтеграційний процес упорядкування господарської діяльності відповідно до чинного податкового законодавства та стратегією розвитку підприємства.

Завдяки такому плануванню можна вибрати оптимальну побудову правових форм відносин і варіанти їх інтерпретації в рамках діючого податкового законодавства. Активна діяльність в цьому напрямку при справедливому посиленню податкового контролю немислима без розуміння загальних принципів податкового планування незалежно від конкретних прикладів.

Очевидно, що в ідеалі податкове планування має бути перспективним, оскільки багато рішень при угодах особливо при великих інвестиційних програмах, дуже дорого обходяться: помилкові дії спричинять великі фінансові втрати. Тому податкове планування має грунтуватися не тільки на вивченні текстів чинного податкового законодавства, а й загальної принципової позиції, займаної податковими органами 3 тих чи інших питань, проектів податкових законів, напрямків і змісту підготовлюваних податкових реформ, а також на аналізі тенденцій в податковій політиці.

Ефективність податкового планування завжди слід співвідносити з витратами на його проведення і стратегічними пріоритетами підприємства.

При описі процесу податкового планування застосовуються різні підходи для визначення його структурних елементів. Так, його можна розбити на чотири взаємопов'язані етапи:

1. Знання податків - точне знання поточного податкового законодавства, його подальшого розвитку; розуміння того, які позитивні або негативні сторони воно має для підприємства.

2. Дотримання податкових законів - своєчасна і чітка підготовка податкових декларацій, звітів, повідомлень та інших документів, повна сплата всіх належних податкових платежів.

3. Взаємовідносини 3 податковими органами - відправка податкових декларацій, звітів, повідомлень та інших документів до податкових органів, надання допомоги податковим органам під час податкових перевірок і на інших етапах дотримання податкових законів, переговори 3 податковими та іншими органами 3 питань порушення податкового законодавства, зниження податків і списання податкової заборгованості, представництво підприємства в судових органах у справах про податкові правопорушення.

4. Податкова оптимізація - планування i управління господарськими операціями для досягнення найбільш вигідною податкової позиції в стратегічній перспективі.

Найефективніший шлях організації податко- вого планування - це інтелектуальне змагання з творцями податкової системи держави. Це надійний i практичний шлях [7,c.95]. Думка підприємця завжди (за визначенням) буде випереджати неповоротку державну машину, у якій зараз практично відсутні аналіз і планування.

У практиці роботи консультантів часто зустрічаються випадки, коли необхідно планувати збалансовані податкові відрахування.

При різкій зміні або значної невідповідності вказаним параметрам підприємство ризикує зазнати позапланової упередженої перевірки контролюючих органів, яка може істотно загальмувати поточну діяльність або зробити ії практично неможливою.

Як правило, ця неприємна процедура при відсутності кваліфікованого юриста або адвоката може закінчитися значними втратами навіть при коректному веденні бухгалтерського обліку.

Крім того, слід віддавати собі звіт, що при сліпому застосуванні податкової мінімізації порушується баланс операцій по іншим операціях, що викликає пильну і справедливе увагу фіскальних служб.

Процес податкового планування - це спільна робота керівника, фінансового аналітика і юриста, яка полягає в пошуку оригінальних рішень і схем роботи, постійному вивченні нормативної бази та спеціальної літератури, а також вивченні і аналізі досвіду інших підприємців (підприємств).

Керівник надає інформацію про умови угоди і про очікувані результати.

Фінансовий аналітик проводить розрахунки варіантів фінансової структури угоди і відображає іiї в бухгалтерському обліку, використовуючи норми чинного податкового законодавства, норми і правила бухгалтерського і фінансового обліку. Він формулює можливі процедури, що вимагають юридичного обгрунтування і узгодження 3 контрагентом і розраховує суми виплат до бюджету з урахуванням податків.

Юрист аналізує процедуру угоди з точки зору правової захищеності, а також готує необхідні документи 3 урахуванням можливих труднощів при іiі проведенні. Допомагає фінансовому аналітику заздалегідь обгрунтувати трактування і вчинення (порядок обліку) угоди і відобразити в бухгалтерській звітності iii результати з урахуванням проблем при іï укладанні. Він розробляє або бере участь в складанні документів податково-правового характеру, здійснює методичне керівництво податково-правовою роботою на підприємстві, надає правову допомогу структурним підрозділам і громадським організаціям у підготовці та оформленні різного роду податкових документів, бере участь в підготовці позовів про визнання недійсними рішень посадових осіб органів податкової служби, міліції про притягнення підприємства, його управлінського персоналу до адміністративної або кримінальної відповідальності. Юрист веде облік і зберігання справ, які знаходяться в провадженні, бере участь в розробці та здійсненні заходів щодо зміцнення договірної, фінансової і трудової дисципліни. Крім того, він вивчає, аналізує та узагальнює результати розгляду судових справ у сфері оподаткування, 
практику укладання та виконання господарських договорів 3 метою розробки пропозицій про усунення виявлених недоліків i поліпшення господарськофінансової діяльності підприємства. Юрист бере участь в роботі з укладення господарських договорів, проведенні їх податково-правової експертизи, веде облік і зберігання чинних законодавчих нормативних актів, виробляє позначки про їх скасування, зміни та доповнення, підготовляє довідкову документацію. Він бере участь у підготовці висновків 3 податковоправових питань, що виникають в діяльності підприємства, проектів нормативних актів, що надходять на відгук. В його обов'язки входить інформування працівників підприємства про чинне податкове законодавство та зміни в ньому, ознайомлення посадових осіб підприємства 3 нормативно-правовими актами 3 їх діяльності, врегулювання податкових суперечок 3 державними органами.

Особливість ролі юриста в податковому плануванні в тому, що він аналізує норми податкового і фінансового законодавства, які неточно визначені або допускається їх неоднозначне тлумачення, також ретельно прогнозує можливі реакції податкових органів.

Наведемо перелік заходів та інструментів податкового планування, які повинні бути в арсеналі юриста i фінансового аналітика групи податкового планування.

Заходи:

- постійний моніторинг нормативно-правової бази;

- дослідження причин відхилень від середньостатистичних показників діяльності організації;

- огляд коментарів фахівців 3 податкової тематики;

- складання прогнозів податкових зобов'язань організації та наслідків планованих схем угод;

- складання графіка відповідності виконання податкових зобов'язань та зміни фінансових ресурсів організації;
- складання прогнозів податкових зобов'язань організації;

- розробка варіантів схем фінансових, документарних і товарно-матеріальних потоків;

- письмове обгрунтування застосованих схем $\mathrm{i}$, особливо, «вузьких місць», з точки зору податкових наслідків;

- прогнозування можливих причин різких відхилень від розрахункових показників діяльності організації;

- прогноз ефективності застосовуваних заходів, оцінка ризику різних програм дій.

Інструменти:

- спеціальна література;

- експертні правові системи, бази даних з податкової тематики;

- формування запитів до податкових інспекцій та інших державних органів;

- господарська та загальногромадянська судова практика.

Висновки і перспективи подальших досліджень. Побудова системи податкового планування починається з визначення стратегічних цілей підприємства в сфері оподаткування. Далі відповідно до цих установок генеруються показники, що дозволяють судити про досяжність і успішність обраних в якості стратегічних орієнтирів нормативів. Виходячи $з$ цього будується організаційна структура процесу податкового планування.

Для того щоб отримати максимальні доходи зі сплатою мінімальних податків, за умови мінливості законодавства та регламентуючих документів, підприємство має застосовувати весь комплекс заходів, що проводяться на оперативному, тактичному і стратегічному рівні податкового планування. Це вимагає застосування знань і навичок фахівців різного профілю - працівників фінансової, бухгалтерської, економічної, юридичної служб.

\section{Література}

1. Про схвалення Стратегії реформування системи управління державними фінансами на 2017-2020 роки: розпорядження Кабінету Міністрів України від 8 лютого 2017 p. № 142-p. URL: https://zakon.rada.gov.ua/laws/show/142-2017(дата звернення 28.04.2021)

2. Вилкова Е., Романовский М. Налоговое планирование. СПб: Питер. 2004 .С 93.

3. Винокуров Д. Оптимизация налогов: практический аспект // Налоги и бухгалтерский учет. 2002. №5. C.5.

4. Голяш І. Д., Романів С.Р., Черешнюк О.М. Податкове планування підприємства як засіб запобігання правопорушенням // Інфраструктура ринку. 2018. №18. С.309 - 312.

5. Єлісєєв А.В., Підлужний М.П. Податкове планування. Мінімізація оподаткування законними способами. Л.: Ліга-Прес, 2003. 274 с.

6. Налоговый менеджмент: учебник / Поршнев А.Г. и др.; под ред. докт.экон.наук, проф., чЛ.-кор РАН А.Г. Поршнева. М.: ИНФРА-М, 2003. С.120.

7. Скворцов Н.Н. Налоговый менеджмент: стратегия и тактика: в 10 кн. - Кн.1: От стагнации к стабилизации: практ. рук. / под ред. В.П. Давыдовой. К.: Вища шк,, 2002. 222 с.

8. Офіційний сайт Державної фіскальної служби України: [Офіційний портал]. Київ. URL: http://sfs.gov.ua/ (дата звернення 2.05.2021)

9. Офіційний сайт Державної податкової служби України: [Офіційний вебпортал]. Київ. URL: https://tax.gov.ua/ (дата звернення 2.05.2021)

10. Вісник. Офіційно про податки: веб-сайт. URL: http://www.visnuk.com.ua (дата звернення 2.05.2021) Стаття надійшла 15.05.2021

Стаття прийнята до друку 29.05.2021 Доступно в мережі Internet 21.07.2021 


\author{
Yevtushevska 0 . \\ $\mathrm{PhD}$, Associate Professor \\ Department of Accounting and Auditing \\ Odessa National Academy of Food Technologies \\ Kanatna str., 112, Odessa, Ukraine, 65039 \\ E-mail: olga163alex@gmail.com \\ ORCID ID: 0000-0003-4869-5123
}

\title{
TAX PLANNING IN THE SYSTEM OF CORPORATE TAX MANAGEMENT
}

The article describes and considers the features of tax management at the micro level, the subject and functions of tax management, discloses the concept of tax planning, describes its main stages, the need and efficiency of tax planning. A list of measures and instruments for tax planning has been provided.

The purpose of any economic activity, as you know, is to make a profit. Therefore, it is important, to create an enterprise even at the stage of planning, to weigh all possible vectors of its development, to provide for the amount of income and expenses.

Tax planning allows, by reducing the cost of paying taxes and mandatory fees to the state and local budgets, to significantly improve the profitability of the business. Such planning must be carried out exclusively with the participation of a specialist (tax consultant, lawyer, financial director, chief accountant, accounting and audit manager) with special knowledge and experience. After all, the main cornerstone here is legality and compliance with current legislation. Tax planning is a system of actions, measures and plans aimed at finding legal ways to reduce the tax burden in today's conditions and in the future. In fact, this is a tool that can significantly reduce the share of the shadow economy in the state. However, unfortunately, in Ukraine, tax planning is used quite rarely and, as a rule, is limited to the calculation of taxes that must be paid after the end of the tax reporting period. But with a correct understanding of the essence of tax planning and the involvement of progressive and experienced specialists, tax amounts can be optimized, freeing up significant amounts for investments in new business areas and new projects.

Key words: the subject of a taxable management, the function of a taxable management, the need for a taxable plan, the efficiency of a taxable plan, taxable planning activities.

\section{References}

1. Rozporiadzhennia Kabinetu Ministriv Ukrainy vid 8 liutoho 2017 r. № 142-r. (2017). Pro skhvalennia Stratehii reformuvannia systemy upravlinnia derzhavnymy finansamy na 2017-2020 roky. zakon.rada.gov.ua. https://zakon.rada.gov.ua/laws/show/142-2017-\%D1\%80\#Text.

2. Vilkova, E., \& Romanovskiy, M. (2004). Nalogovoe planirovanie. Piter.

3. Vinokurov, D. (2002). Optimizatsiya nalogov: prakticheskiy aspekt. Nalogi i Buhgalterskiy Uchet, (5), 5.

4. Holiash, I. D., Romaniv, S.R., \& Chereshniuk, O.M. (2018). Podatkove planuvannia pidpryiemstva yak zasib zapobihannia pravoporushenniam. Infrastruktura rynku. (18), $309-312$.

5. Yelisieiev, A.V., \& Pidluzhnyi, M.P. (2003). Podatkove planuvannia. Minimizatsiia opodatkuvannia zakonnymy sposobamy. Liha-Pres.

6. Porshnev, A. G. (2003). Nalogovyiy menedzhment. (A. G. Porshnev, Ed.). INFRA-M. Vischa shk.

7. Skvortsov, N. N. (2002). Nalogovyiy menedzhment: strategiya i taktika. (V. P. Davyidova, Ed.) (Vol. 1).

8. Ofitsiinyi sait Derzhavnoi fiskalnoi sluzhby Ukrainy. Ofitsiinyi portal. (2021). http://sfs.gov.ua/

9. Ofitsiinyi sait Derzhavnoi podatkovoi sluzhby Ukrainy. Ofitsiinyi vebportal. (2021). https://tax.gov.ua/

10. Visnyk. Ofitsiino pro podatky. (2021). http://www.visnuk.com.ua

Received 15 May 2021 Approved 29 May 2021 Available in Internet 21.07.2021

Цитування згідно ДСТУ 8302:2015

Євтушевська О.О. Податкове планування у системі корпоративного податкового менеджменту // Економіка харчової промисловості. 2021. Т. 13, вип. 2. С. 34-38. doi: 10.15673/fie.v13i2.2038

Cite as APA style citation

Yevtushevska, O. (2021). Tax planning in the system of corporate tax management. Food Industry Economics, 13(2), 34-38. doi: 10.15673/fie.v13i2.2038 